\title{
Prolactin-producing pituitary adenoma with atypical spindle cell morphology: a case report
}

\author{
Ritsurou Inoue ${ }^{1}$, Mikiko Aoki ${ }^{2 *}$, Yoshihisa Matsumoto ${ }^{1}$, Seiji Haraoka ${ }^{3}$, Kiyoshi Kazekawa ${ }^{1}$ and Kazuki Nabeshima ${ }^{2}$
}

\begin{abstract}
Reported herein is a 25-year-old woman who was treated for a large and highly atypical prolactin-producing pituitary adenoma. On presentation, she exhibited right hemiparesis and left-sided visual loss, associated with amenorrhea. A massive $(>5 \mathrm{~cm})$ intra- and suprasellar lesion was seen on imaging, and her serum prolactin level was $4408 \mathrm{ng} / \mathrm{ml}$. The patient received dopamine agonist treatment preoperatively for 4 weeks. To resect the tumor, a two-stage excision was required. Histologically, the specimen was composed of polygonal or spindle cells showing marked nuclear pleomorphism and/or multinucleation. Fibrosis was also focally conspicuous. Differential diagnoses included pituitary adenoma, pituitary carcinoma, pituicytoma, paraganglioma, spindle cell oncocytoma, and meningioma. Immunohistochemically, the tumor cells were positive for prolactin, chromogranin-A, and synaptophysin, but were negative for glial fibrillary acidic protein, S-100 protein, epithelial membrane antigen, and vimentin. No apparent cerebrospinal or systemic metastases are found. Ultimately, prolactin-producing pituitary adenoma was diagnosed. Our case highlights the difficulty in definitively diagnosing an unusual prolactin-producing adenoma based on histopathology alone and the importance of referring to clinical information and immunohistochemical findings when deriving the diagnosis.
\end{abstract}

Keywords: Pituitary adenoma, Prolactin, Morphologic atypia, Spindle cell

\section{Background}

In tissue sections, prolactin (PRL)-producing pituitary adenomas typically present as monotonous arrays of chromophobic cells in diffuse, papillary, or sinusoidal proliferations. Such cells generally are of uniform size, lacking both nuclear atypia and mitotic figures. Cystic change, bleeding, or calcification may be observed in the event of pituitary apoplexy. Likewise, dopamine agonist therapy may alter tumor histology, resulting in negative immunoreactivity for PRL; cellular shrinkage, degeneration, or necrosis; acellular or fibrotic areas; and other effects [1-3].

In this report, an unusual occurrence of prolactinoma is detailed. As opposed to the ordinarily bland picture of such lesions, the alarming degree of atypia we observed raised suspicions of pituitary carcinoma, paraganglioma, and pituicytoma. The histologic attributes of this particular

\footnotetext{
* Correspondence: mikikoss@fukuoka-u.ac.jp

${ }^{2}$ Department of Pathology, School of Medicine, Fukuoka University, 7-45-1

Nanakuma, Jonan-ku, Fukuoka 814-0180, Japan

Full list of author information is available at the end of the article
}

tumor are discussed herein, supplemented by findings in prior publications.

\section{Case presentation}

A 25-year-old female patient had noticed left-sided visual loss and amenorrhea 2 years prior to being seen, with right hemiparesis developing 6 months beforehand. Aggravated symptoms (drooping at corner of right lip and bilateral temporal hemianopia) finally prompted hospitalization. At that time, a massive $(>5 \mathrm{~cm})$ tumor of intra- and suprasellar location, excluding mesencephalon backward, was seen on computerized tomography (CT) of the head (Fig. 1a). Further testing revealed an exceedingly high-serum level of prolactin (PRL) (4408 ng/ml), whereas levels of all other pituitary hormones were within reference ranges (growth hormone $(\mathrm{GH}), 0.50 \mathrm{ng} / \mathrm{ml}$; luteinizing hormone (LH), $2.60 \mathrm{mIU} / \mathrm{ml}$; folliclestimulating hormone (FSH), $4.57 \mathrm{mIU} / \mathrm{ml}$; adrenocorticotropic hormone (ACTH), $37.4 \mathrm{pg} / \mathrm{ml}$; thyroid-stimulating hormone (TSH), $2.68 \mu \mathrm{IU} / \mathrm{ml}$ ). T1-weighted magnetic resonance (MR) imaging with contrast (gadolinium) showed homogeneous tumor enhancement, but adjacent tissue 


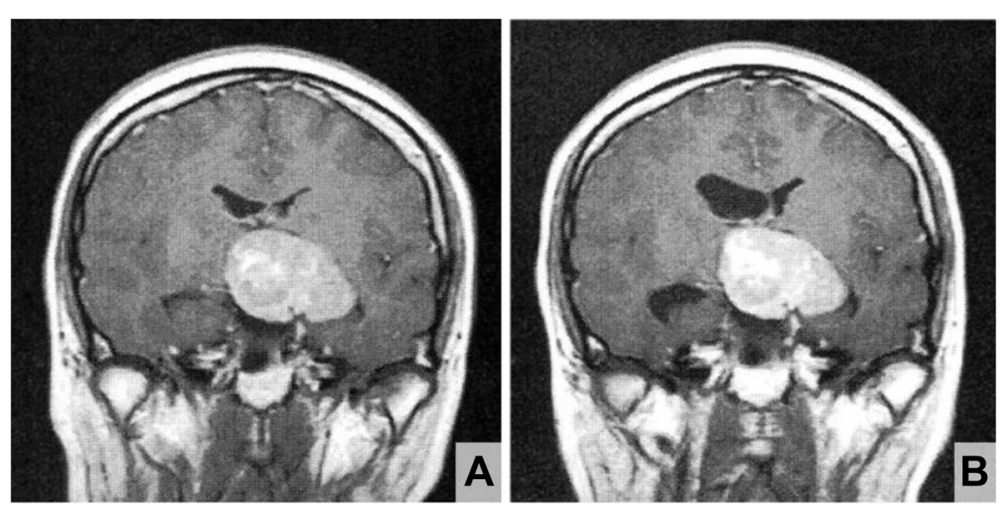

Fig. 1 Pretreatment (a) and preoperative (b) coronal T1-weighted magnetic resonance images with contrast (gadolinium). Prior to surgery, slight dilatation of right lateral ventricle evident (b), compared with baseline status (before cabergoline therapy) (a)

was not edematous in T2-weighted views. The mass did not regress, despite a 4-week course of the dopamine analog, cabergoline (1 mg/week), and serum PRL level $(2207 \mathrm{ng} / \mathrm{ml})$ remained elevated. Relative to status at admission, the right lateral ventricle also had enlarged somewhat, due to obstruction at foramen of Monro (Fig. 1b). In light of this intransigence, surgical debulking of tumor was elected first, through craniotomy and then via transsphenoidal approach. The hardened elastic quality of the tumor and its strong attachments to neighboring structures prevented complete removal, but related mass effect was significantly reduced and serum PRL level declined (to $250 \mathrm{ng} / \mathrm{ml}$ ) in steps at each procedural stage. But the normalization of PRL level had not been achieved with the administration of cabergoline increased up to $0.5 \mathrm{mg} /$ day. The residual tumor showed no evidence of regrowth or distant metastasis 1 year after surgery.

Histopathologically, hematoxylin and eosin (H\&E)stained sections of specimens from the first and second surgical procedures similarly were composed of polygonal and spindle cells with round, oval, or elongated nuclei and eosinophilic cytoplasm (Fig. 2a-c). The cells formed irregular nests or short fascicles, accompanied by frequent hyaline changes in vessel walls and vacuolation (Fig. 2d). Some nuclear pleomorphism was prominent; on the other hand, neither a high mitotic rate nor necrosis was evident (Fig. 2b, c). Conspicuous fibrous change of tumor stroma was noted focally as well (Fig. 3a). The chromophobic nature of tumor cells was confirmed by Pearse's Periodic Acid Schiff (PAS) stain (Fig. 3b). Immunostains showed strong diffuse
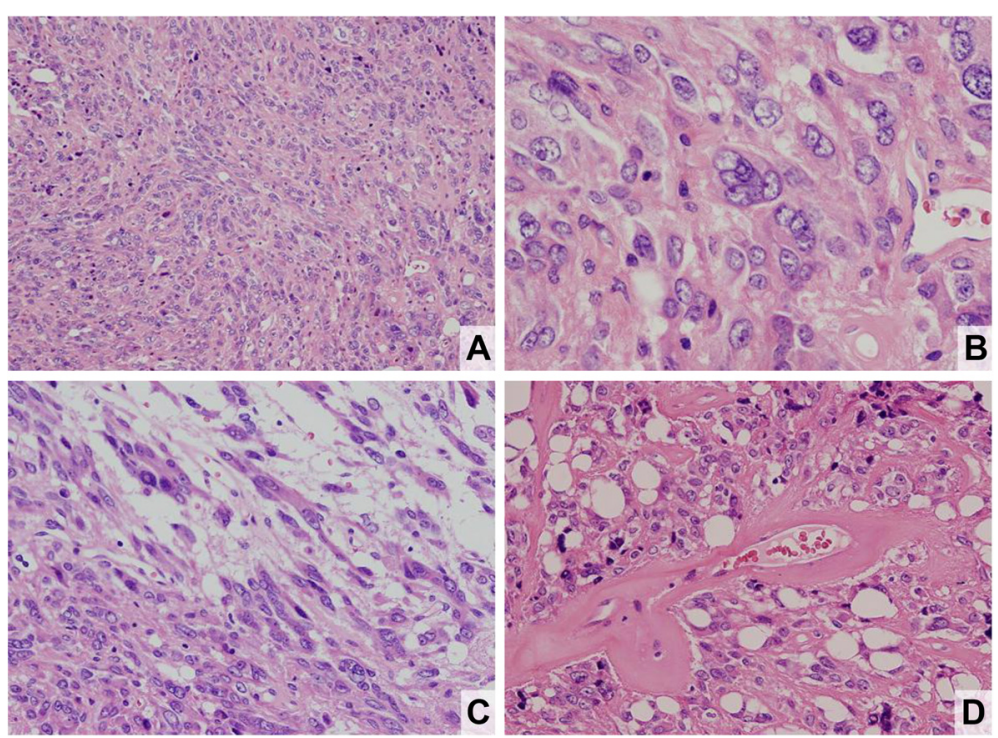

Fig. 2 H\&E staining of prolactinoma. Pleomorphic ovoid tumor cells in dense and disorderly proliferation (a); atypical multinucleated giant cells and prominent nucleoli seen in higher magnification (b); proliferation of spindle cells with elongated nuclei and prominent nucleoli (c); hyalinized vessel walls as frequent finding (d) 


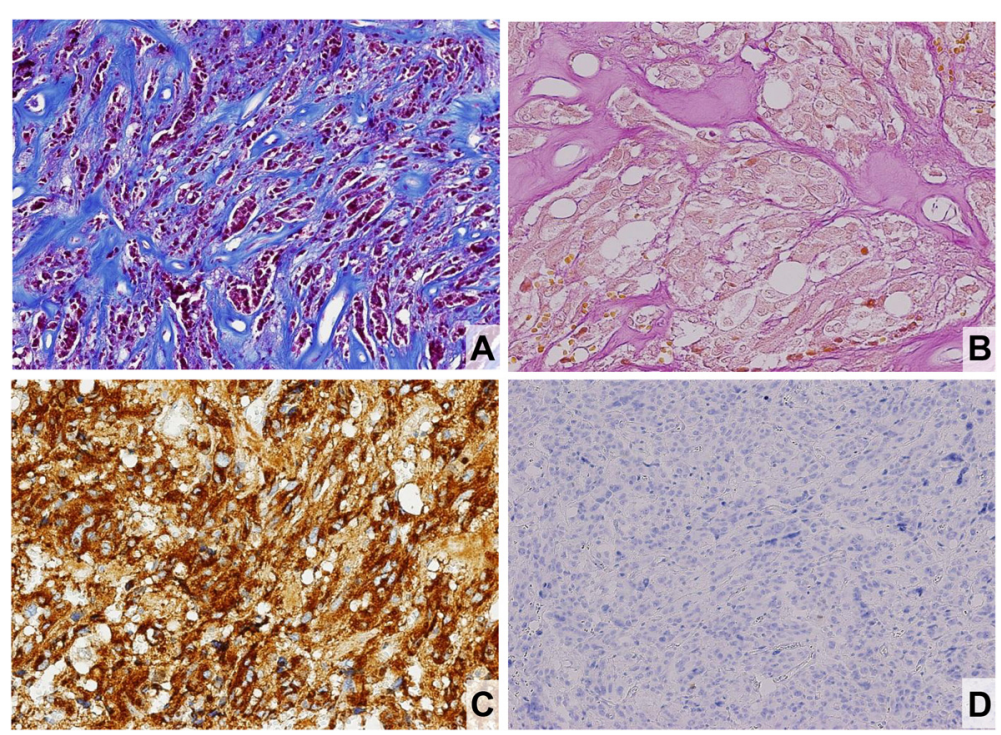

Fig. 3 Immunohistochemistry of prolactinoma. Conspicuous fibrous change in tumor confirmed by Masson trichrome stain (a); Pearse's PAS stain verifying chromophobic tumor cells (b); strong reactivity of tumor cells for PRL, with paranuclear localization (c); tumor cells negative for S-100 protein (d)

positivity for PRL (Fig. 3c), chromogranin-A, and synaptophysin. No other hormones (GH, TSH, ACTH, LH, FSH) were expressed by tumor cells, and the other markers, including S-100 protein (Fig. 3d), glial fibrillary acidic protein (GFAP), epithelial membrane antigen (EMA), cytokeratin AE1/AE3 (CK AE1/AE3), vimentin, p53, and bcl-2, were also negative by immunostaining. Ki-67 labeling index was approximately $2 \%$.

A final diagnosis of PRL-producing pituitary adenoma was reached after considering the immunohistochemical profile, suprasellar location, and prolactin production of the tumor, as well as the absence of metastatic foci and invasion into surrounding tissue.

\section{Discussion}

The histopathologic traits of this tumor were highly unusual. Uniform, rounded, or polygonal cells with roundto-oval nuclei are typically seen in pituitary adenomas. In ordinary pituitary adenomas, cells are arranged in a perisinusoidal fashion, and mitotic figures or necrotic cells are rare. However, tumor morphology is known to change following dopamine agonist (DA) treatment. Moritetsu et al. reported necrotic changes in prolactinomas after long-term administration of bromocriptine, also identifying acellular areas (from tumor involution) where hyaline deposition and fibrosis were variably seen and describing visible tumor atypism (hyperchromatic or giant nuclei) [1]. After short-term exposure to DA, apoptotic cells/bodies [2] and multinucleated giant cells may be present [3], but fibrous change is exceptional. In those instances where use of DA has altered tumor morphology, therapeutic efficacy is commonly signaled by tumor involution and/or decline in serum PRL level, plus diminished PRL immunoreactivity (especially in the small cells that populate prolactinomas) [4]. In the patient reported here, broad fascicular fibrosis of tumor was focally conspicuous, and overt cellular atypia was observed, even though a relatively short course (4 weeks) of medical therapy was given preoperatively. Considering that the serum PRL level on admission was lowered by nearly one half through medication, the effects of DA may account for some of these manifestations. However, PRL immunoreactivity persisted postoperatively, without apoptotic changes or necrosis, none of this in keeping with response to DA. The stromal fibrosis may possibly reflect the longer period of growth and greater size of this lesion. There have been sporadic reports of pituitary adenomas that histologically show cellular atypia and bizarre nuclei. Matsumoto et al. have also documented a growth-hormone-producing giant pituitary adenoma with marked cellular atypia, and Moriwaki et al. have a recurrent pituitary adenoma harboring huge, bizarre nuclei [5].

In instances where an intracranial mass and hyperprolactinemia coexist, dysfunction of the hypophyseal stalk due to the mass effect of various tumors (i.e., chordoma, schwannoma, paraganglioma, or mixed germ cell tumor) [6] and tumors arising near sella, other than prolactinoma, must be considered. Differential diagnosis was required since the histological findings in this case were different from that of typical pituitary adenoma. In particular, the proliferation of spindle cells was striking, implicating a host of diagnostic possibilities (see Table 1). Spindle cell oncocytoma (SCO) contains fascicles of eosinophilic spindle cells with granular cytoplasm, and its immunophenotype is 
Table 1 Histology and immunostaining in differential diagnosis of tumors

\begin{tabular}{|c|c|c|c|c|c|c|c|}
\hline Staining & $\begin{array}{l}\text { Case } \\
\text { presentation }\end{array}$ & Pituitary adenoma & Pituicytoma & Paraganglioma & $\begin{array}{l}\text { Spindle cell } \\
\text { oncocytoma }\end{array}$ & Meningioma & $\begin{array}{l}\text { Granular cell } \\
\text { tumor }\end{array}$ \\
\hline Histology & $\begin{array}{l}\text { See text } \\
\text { and Fig. } 2\end{array}$ & $\begin{array}{l}\text { Monotonous } \\
\text { arrays of } \\
\text { chromophobic } \\
\text { cells in diffuse, } \\
\text { papillary, or } \\
\text { sinusoidal } \\
\text { proliferation }\end{array}$ & $\begin{array}{l}\text { Variably lobulated } \\
\text { sheets of cells with } \\
\text { copious cytoplasm } \\
\text { and round, uniform } \\
\text { nuclei with small } \\
\text { nucleoli }\end{array}$ & $\begin{array}{l}\text { Nested pattern } \\
\text { (Zellballen } \\
\text { configuration) } \\
\text { and rimmed by } \\
\text { sustentacular } \\
\text { cells }\end{array}$ & $\begin{array}{l}\text { Eosinophilic } \\
\text { spindle-shaped or } \\
\text { polygonal cells with } \\
\text { granular cytoplasm } \\
\text { (abundant } \\
\text { mitochondria) }\end{array}$ & $\begin{array}{l}\text { Spindle or } \\
\text { polygonal cells } \\
\text { with large oval } \\
\text { nuclei and } \\
\text { indistinct cell } \\
\text { borders }\end{array}$ & $\begin{array}{l}\text { Abundant } \\
\text { granular } \\
\text { eosinophilic } \\
\text { cytoplasm with } \\
\text { round } \\
\text { monomorphic } \\
\text { nuclei }\end{array}$ \\
\hline $\begin{array}{l}\text { Pituitary } \\
\text { hormones }\end{array}$ & \pm & \pm & - & - & - & - & - \\
\hline Cytokeratin & - & \pm & - & - & - & $5 \%$ & - \\
\hline EMA & - & $>50 \%$ & - & - & + & + & - \\
\hline S-100 protein & - & - & + & + & + & $20 \%$ & + \\
\hline Vimentin & - & - & - & \pm & + & + & + \\
\hline GFAP & - & - & + & \pm & - & - & \pm \\
\hline Synaptophysin & + & + & - & + & - & - & - \\
\hline $\begin{array}{l}\text { Chromogranin- } \\
\text { A }\end{array}$ & + & $90 \%$ & - & $95 \%$ & - & - & - \\
\hline
\end{tabular}

EMA epithelial membrane antigen, GFAP glial fibrillary acidic protein

distinctive (positive for vimentin, EMA, and S-100; negative for pituitary hormones, synaptophysin, chromogranin, and cytokeratins) [7]. Pituicytoma consists of elongated, bipolar spindle cells in interlacing fascicles or storiform array, with variable immunopositivity for vimentin, S-100 protein, and GFAP [7]. Paragangliomas regularly exhibit nested patterns (Zellballen configuration) and are rimmed by sustentacular cells. The latter generally are immunopositive for GFAP, chromogranin-A, and neuron-specific enolase, and sustentacular cells are positive for S-100 protein [8].

This patient's tumor cells were giant atypical nuclei, giving the impression of malignancy. Pituitary carcinomas do not always show nuclear atypia, pleomorphism, necrosis, and hemorrhage as conventional indicators of malignancy, but mitotic count or Ki-67 labeling index is apt to be increased, with a clear tendency for cerebrospinal or systemic metastases. In this case, the tumor cells were proven chromophobic by Pearse's PAS stain, showing immunopositivity for PRL, chromogranin-A, and synaptophysin but no immunoreactivity to S-100 protein, vimentin, and GFAP. Mitotic figures were scarce in tissue samples, and the Ki-67 labeling index was approximately $2 \%$. This immunohistochemical profile is quite compatible with pituitary adenoma. The details of antibodies used for immunohistochemical study are summarized in Table 2.

Table 2 Antibodies used for immunohistochemical study

\begin{tabular}{lllll}
\hline Primary antibody & Source & Pretreatment & Category & Dilution \\
\hline PRL & DAKO & None & Rabbit polyclonal & $1: 1500$ \\
GH & DAKO & None & Rabbit polyclonal & $1: 1500$ \\
FSH & DAKO & None & Mouse monoclonal & $1: 100$ \\
ACTH & DAKO & None & Mouse monoclonal & $1: 2500$ \\
Cytokeratin & Leica BOND & Proteinase K & Mouse monoclonal & $1: 100$ \\
EMA & DAKO & Tris/EDTA pH 8 & Rabbit polyclonal & $1: 100$ \\
S-100 protein & Nichirei & None & Mouse monoclonal \\
Vimentin & Leica BOND & Tris/EDTA pH 8 & Mouse monoclonal \\
GFAP & Leica BOND & Tris/EDTA pH 8 & Mouse monoclonal \\
Synaptophysin & Leica BOND & Tris/EDTA pH 8 & Mouse monoclonal \\
Chromogranin-A & DAKO & Tris/EDTA pH 8 & Mouse monoclonal & $1: 200$ \\
bcl-2 & DAKO & Tris/EDTA pH 8 & Mouse monoclonal & $1: 100$ \\
TP53 & Leica BOND & Tris/EDTA pH 8 & Mouse monoclonal \\
Ki-67 & DAKO & Tris/EDTA pH 8 & $1: 1000$ \\
\hline
\end{tabular}




\section{Conclusions}

Herein, we describe a patient who underwent treatment for a sizeable and visibly atypical prolactinoma. Similar to PRL-producing adenomas, sellar tumors also may exhibit hyperprolactinemia. Furthermore, DA administration can cause secondary changes in the histological appearance of the tumor. Thus, histopathological diagnosis can be extremely challenging in cases of PRL-producing adenomas characterized by remarkable spindle-shaped cells with nuclear pleomorphism, as described in the present study.

\section{Consent}

Written informed consent was obtained from the patient for publication of this case report and the accompanying images. A copy of the written consent is available for review by the editor-in-chief of this medical journal.

\section{Abbreviations \\ ACTH: adrenocorticotropic hormone; DA: dopamine agonist; EMA: epithelial membrane antigen; FSH: follicle-stimulating hormone; GFAP: glial fibrillary acidic protein; GH: growth hormone; LH: luteinizing hormone; PRL: prolactin; TSH: thyroid-stimulating hormone.}

\section{Competing interests}

The authors declare that they have no competing interests.

\section{Authors' contributions}

$\mathrm{RI}$ and MA analyzed previous published data and wrote the manuscript. RI, $\mathrm{SH}$, and $\mathrm{KN}$ evaluated biopsy specimens, chose the panel of antibodies for immunohistochemical study, evaluated the staining, and made final agreed report. KK and YM participated in the treatment of the patient. All authors read and approved the final manuscript.

\section{Acknowledgements}

This study received no financial support.

\section{Author details}

${ }^{1}$ Department of Neurosurgery, Fukuoka University Chikushi Hospital, 1-1-1 Zokumyoin, Chikushino, Fukuoka 818-8502, Japan. ²Department of Pathology, School of Medicine, Fukuoka University, 7-45-1 Nanakuma, Jonan-ku, Fukuoka 814-0180, Japan. ${ }^{3}$ Department of Pathology, Fukuoka University Chikushi Hospital, 1-1-1 Zokumyoin, Chikushino, Fukuoka 818-8502, Japan.

Received: 19 April 2015 Accepted: 20 July 2015

Published online: 31 July 2015

\section{References}

1. Gen M, Uozumi T, Ohta M, Ito A, Kajiwara H, Mori S. Necrotic changes in prolactinomas after long term administration of bromocriptine. J Clin Endocrinol Metab. 1984;59(3):463-70.

2. Kontogeorgos G, Horvath E, Kovacs K, Coire C, Lloyd RV, Scheithauer BW, et al. Morphologic changes of prolactin-producing pituitary adenomas after short treatment with dopamine agonists. Acta Neuropathol. 2006;111(1):46-52. Epub 2005 Nov 23.

3. Kupersmith MJ, Kleinberg D, Warren FA, Budzilovitch G, Cooper P. Growth of prolactinoma despite lowering of serum prolactin by bromocriptine. Neurosurgery. 1989;24(3):417-23.

4. Kovacs K, Stefaneanu L, Horvath E, Lloyd RV, Lancranjan I, Buchfelder M, et al. Effect of dopamine agonist medication on prolactin producing pituitary adenomas. A morphological study including immunocytochemistry, electron microscopy and in situ hybridization. Virchows Arch A Pathol Anat Histopathol. 1991;418(5):439-46.

5. Matsumoto K, Ikezaki F, Miyamoto S, Sakaki Y, Yagihashi S. Growth hormone-producing giant pituitary adenoma with marked cellular atypia. J Jpn Soc Clin Cytol. 2000;39(3):199-203.
6. Wang HF, Ma HX, Ma CY, Luo YN, Ge PF. Sellar chordoma presenting as pseudo-macroprolactinoma with unilateral third cranial nerve palsy. Chin J Cancer Res. 2012;24(2):167-70. doi:10.1007/s11670-012-0167-y.

7. Ogiwara H, Dubner S, Shafizadeh S, Raizer J, Chandler JP. Spindle cell oncocytoma of the pituitary and pituicytoma: two tumors mimicking pituitary adenoma. Surg Neurol Int. 2011;2:116. doi:10.4103/2152-7806.83932. Epub 2011 Aug 17.

8. Chaudhry NS, Ahmad F, Blieden C, Morcos JJ. Suprasellar and sellar paraganglioma presenting as a nonfunctioning pituitary macroadenoma. J Clin Neurosci. 2013;20(11):1615-8.

\section{Submit your next manuscript to BioMed Central and take full advantage of:}

- Convenient online submission

- Thorough peer review

- No space constraints or color figure charges

- Immediate publication on acceptance

- Inclusion in PubMed, CAS, Scopus and Google Scholar

- Research which is freely available for redistribution 